\title{
CONSTITUtional PREVIEW AND REVIEW OF INTERNATIONAL TREATIES: FRANCE AND INDONESIA COMPARED
}

\author{
Dewi Nurul Savitri* \\ University of Paris 1 Panthéon Sorbonne \\ Dewi-Nurul.Savitri@etu.univ-parisı.fr
}

\begin{abstract}
The Indonesian Supreme Court and the Indonesian Constitutional Court are experienced in examining international treaties, although the Indonesian constitution and national laws do not stipulate this matter explicitly. The Constitutional Council of France has the authority to examine judicial previews of bills concerning international treaties. Moreover, French judges can examine international treaties. There is also the European Court of Human Rights, which has an important role concerning the control of conventionality. This article aims to promote discussion about the examination of international treaty cases in Indonesia. It begins by considering the international scholarly literature on integrating international treaties and the rank of international treaties in the national legal system. Then, this article discusses the possibility of the Indonesian Constitutional Court to examine judicial preview of international treaty bills and judicial reviews concerning ratified international treaties.
\end{abstract}

Keywords: Constitutional Court, Constitutional Council, France, Indonesia, International Treaty.

\section{INTRODUCTION}

In the globalize era, the dynamics of foreign policy are very important when implemented by each country as a subject of international law. Discussion on the subject of foreign policy and international treaties has been very interesting because it reflects not only the legal system and the political dynamics between

* Doctoral candidate of Comparative Law Department at University of Paris 1 Panthéon Sorbonne, France. 
the president, the House of Representatives and the courts, but also the legal culture of a state. An interesting question raised by an Asian student: why does an international treaty have a higher position in France than the national law? At the same time, the highest position an international treaty can achieve in Indonesia is no more than equal to the national law.

Based on the legal culture of France, an international treaty plays a highly valuable role in securing peace between countries, particularly countries in Europe. Following the Second World War, the European Convention on Human Rights was signed in Rome on 4 November 1950, engaging 47 states from Western, Central and Eastern Europe. ${ }^{.}$The idea of the European Convention on Human Rights was inspired directly by the Universal Declaration of Human Rights, adopted by the General Assembly of the United Nations on 10 December 1948. The European Convention on Human Rights is the work of the Council of Europe, whose statutes specifically require any member states to recognise the principle of the rule of law and the principle that any person placed under its jurisdiction must enjoy human rights and fundamental freedoms.

According to the legal culture in Indonesia, the primary position in law is given to the sovereignty of Indonesian people, as stated in the second paragraph of the Constitution preamble: "Indonesia has now reached the moment of rejoicing to guide the Indonesian people safely and soundly to the threshold of the independence of the State of Indonesia, which is independent, united, sovereign, just and prosperous." ${ }^{2}$ Indonesia also participated in the world order based on its independence, perpetual peace and social justice, as mentioned in the fourth paragraph of the Constitution's preamble. ${ }^{3}$ Furthermore, Indonesia also created the ASEAN Human Rights Declaration, signed on 18 November 2012 and committed to by 10 member states in the Association of Southeast Asian Nations for the purpose of promoting and protecting human rights and fundamental freedoms. ${ }^{4}$

\footnotetext{
The European Convention on Human Rights has an official name, the "Convention for the Protection of Human Rights and Fundamental Freedoms" and it came into effect on 3 September 1953.

Second paragraph of the Preamble of Indonesian constitution of 1945, dated 18 August 1945 .

Fourth paragraph of the Preamble of Indonesian constitution of 1945, dated 18 August 1945 .

See point 6 for the general principles of the ASEAN Human Rights Declaration. The 10 countries of ASEAN
} 
Concerning the European Convention on Human Rights, France implemented the control of conventionality (le contrôle de conventionnalité) as a control to secure conformity to international conventions with the aim of assuring the superiority of the international convention. On the contrary, Indonesia does not have the legal system of the control of conventionality, although commitments were made to the ASEAN Human Rights Declaration. Nevertheless, the Indonesian public applied cases relating to international treaties to the Supreme Court and the Constitutional Court. However, these two courts consider the legality of international treaties differently.

In this article, the author aims to demonstrate the examination of international treaty cases in France and Indonesia and also how the Indonesian Constitutional Court can examine judicial previews of international treaty bills and judicial reviews concerning ratified international treaties. The author compares the legal system between France and Indonesia because based on the history, Indonesia was colonized by the Netherlands. On the other hand, the Netherlands was conquered by France during Napoleon Bonaparte's imperialism and he appointed his brother, Louis Napoleon, as a King of Netherlands in 18065. After Indonesia's independence on $17^{\text {th }}$ August 1945, Indonesia adopted Netherland's laws based on Article II of the Indonesian Constitution ${ }^{6}$. Therefore, Indonesia assents Code of Napoleon such as Code civil and Code criminal by the concordance principle. However, this article does not compare the international treaty reviewed. by Netherlands because based on Article 120 of the Netherlands Constitution "The constitutionality of Laws of Parliament and treaties shall not be reviewed by the courts"7. Moreover, France has experienced in solving international treaties problems in its legal system.

members that signed the ASEAN Human Rights Declaration are Brunei Darussalam, the Kingdom of Cambodia, the Republic of Indonesia, the Lao People's Democratic Republic, Malaysia, the Republic of the Union of Myanmar, the Republic of the Philippines, the Republic of Singapore, the Kingdom of Thailand and the Socialist Republic of Viet Nam.

5 Article 2 of the Treaty of 24 May 1806 between the Republic of Batavia and the French Emperor who established the Royalty of Holland.

6 Article II of the Indonesian Constitution stipulate, "All existing state institutions shall remain functioning to the extent of executing the provisions of the Constitution and no new ones are provided according to this Constitution".

7 The Netherlands Constitution, Art. 120, 2008. 
The discussion begins by explaining the integration of international treaties in the national legal system, which consists of theories of monism and dualism, as well as the procedure of ratification approval. Furthermore, the author discusses the rank of international treaties in the national legal system by describing the hierarchy of norms. Finally, the author describes international treaty cases examined by courts in France and Indonesia before trying to resolve the legal problems in examining international treaty cases encountered by the Indonesian Constitutional Court.

\section{DISCUSSION}

In the separation of powers, the president as the executive branch and the parliament as the legislative branch are the political actors that make laws. As a judicative branch, judges play their role as political actors to the extent that they examine the conformity of laws to the constitution. They also harmonize with political dynamics, including the implementation of international law into the national legal system. In this context, David Sloss and Michael Van Alstine were of the opinion that "domestic courts are created by their home polity, so that the relative influence of law and politics in the work of domestic judicial bodies, therefore, is of intense scholarly interest." ${ }^{8}$

This article uses the method of comparison approach as a function consisting of the discovery of a legal way to solve a legal problem and justify the solution according to a specific context. ${ }^{9}$ In the context of the constitutionality of international treaties, France and Indonesia have the president and the parliament to integrate international treaties into the national law, and also the court to examine laws related to international treaties. According to the Venice Commission, "courts are key actors which exercise in a meaningful way the review of the compatibility of domestic legislation with international human rights

8 David Sloss and Michael Van Alstine, "International Law in Domestic Courts" (Paper at Santa Clara Law Digital Commons, 2015), 2. https://digitalcommons.law.scu.edu/cgi/viewcontent.cgi?article=1891\&context=facpubs.

9 Barrué-Belou, "Méthode et enjeux de la démarche comparative: la question de la comparabilité [Methodology and challenges of the comparative approach : the question of comparability]," http://www.droitconstitutionnel. org/congresNancy/comN4/barrueBelouTD4.pdf. 
treaties."10 However, the legal system between these two countries is completely different due to their diverse legal cultures. We can study this comparison in order to complete the national legal system concerning the implementation of international treaties in accordance to the legal culture in Indonesia.

\subsection{Integration of International Treaties in the National Legal System}

International treaties are legal rules negotiated by several states with the purpose of making a commitment mutually in certain fields such as defence, trade and justice. The integration of international treaties is transformed into domestic law, either through international treaties becoming national law automatically or becoming incorporated into national law."

France and Indonesia have their own procedures in order that international treaties can be implemented in their national legal systems. However, these two countries use different theories in integrating international treaties: namely, the theories of monism and dualism. The Presidents of the Republic in France and Indonesia have an important role as the head of state in integrating international treaties. Moreover, the parliament can intervene in the ratification process of international treaties. Therefore, this part is divided into discussing theories of monism and dualism, as well as the ratification approval in integrating international treaties.

\subsubsection{Theory of Monism vs. theory of Dualism}

Referring to the report of the Venice Commission on the implementation of international human rights treaties in domestic law and the role of courts,

The distribution of competences between the legislator, the executive and the courts varies greatly depending on the monist or dualist approach of the country concerned, on the internal effect of the specific international legal provision, on the status of international human rights treaties and on the powers of the

\footnotetext{
10 Veronika Bilkova. et. al., "Report on the Implementation of International Human Rights Treaties in Domestic Law and the Role of Courts" (Report, Report, European Commission for Democracy through Law (Venice Commission), 2014), 3. https://www.venice.coe.int/webforms/documents/default.aspx?pdffile=CDL-AD(2014)036-e.

${ }_{11}$ Christine Kaufmann and Johannes Chan, "The relationship between international and national law in China, Hong Kong, and Switzerland" (Paper at Seinar Comparative Constitutional Law, 2008), 8-9. http://www.ivr.uzh. ch/dam/jcr:ffffffff-ec76-c8fg-0000-00004e58ddad/Pleisch_Rafaela.pdf.
} 
courts. The theories of monism and dualism evolved from the end of nineteenth century until the beginning of the twentieth.

Based on the theory of monism, there is a continuity between the international order and the national order, but the postulates are radically different. The subject is necessarily an individual, with the ultimate objective of any rule of law to govern individual behaviour. Whatever the form of monism, the state only serves to designate those who will have to implement international rules. ${ }^{12}$ According to Damos Dumali Agusman, the theory of monism places international law and national law both as parts of a unified legal system. The international law applies within the scope of the national without passing through a transformation process. ${ }^{13} \mathrm{~A}$ country which has embraced the monism theory cannot reject international law because international law is a part of the national legal system. ${ }^{14}$

The monism theory is divided in two branches: namely, the monism of the superiority of national law and the monism of the superiority of international law. The monism of the superiority of national law considers that international law derives from the domestic, so that the domestic law is superior to the international, and the international law is only a kind of the public external law of the state. ${ }^{5}$ On the other hand, the monism of the international law considers that the domestic derives from the international law, so that the international law is superior to the domestic, which it conditions, and the relations between international and domestic law would be comparable to those existing between the law of member states and national law. ${ }^{16}$

Hans Kelsen developed the monism theory. According to Kelsen, the international legal order not only requires the national legal orders to form

12 "L'application du droit international dans l'ordre internet [The application of international law in the internal order]," Le cours de droit.net. http://www.cours-de-droit.net/integration-du-droit-international-en-droit-internedualisme-monisme-a121610042.

13 Damos Dumali Agusman, "Status Hukum Perjanjian Internasional Dalam Hukum Nasional Republik Indonesia, Tinjauan Dari Perspektif Indonesia [The Legal Status of International Treaties in the National Law of the Republic of Indonesia, A Review of Indonesia's Perspective]," Indonesia Journal of International Law, vol. 5 (2008): 489.

14 Kaufmann and Chan, "The relationship between" 8.

15 "Les rapports du droit international et du droit interne" [The reports of the international law and the domestic law], http://droit.univ-lille2.fr/fileadmin/user_upload/enseignants/lavenue/DIP/dip_1_5.pdf

16 lbid. 
a necessary complement, but it also determines their sphere of validity in all respects. The national law and international law forms are inseparable. ${ }^{17}$ For Kelsen, the supremacy of international law is one possible option for constructing the hierarchical monistic legal universe to explain how international law could be used to implement policy projects by new institutions and laws related to national and international levels, for example, by directly authorising and holding to account private actors of international law in the monism legal system. ${ }^{18}$

A student of Hans Kelsen, Alfred Verdross (1890 - 1980), stated that monism theory establishes the primacy international law in the hierarchy of legal orders where universalism is applied to positive law.19 Moreover, Verdross express his opinion that the universalist concept is rooted in the Stoic-Christian view that, on the whole, humanity forms a moral-legal unity rooted in natural law. ${ }^{20}$ Natural law retains its relevance in international legal theory in order to understand the changing norms fora political organisation in a global community. ${ }^{21}$

France embraces the monism theory. Based on paragraph 14 of the Preamble of the French Constitution, "The French Republic shall respect the values of Public International Law". ${ }^{22}$ Furthermore, paragraph 15 of the Preamble of the French Constitution stipulates, "France shall consent to the limitations upon its sovereignty necessary for the organization and preservation of peace"..23 Since the constitutional accession of France to monism in 1946, international treaties have been ratified and published in order to be integrated into the internal legal order and have direct effects on national law. ${ }^{24}$ In this regard, monism theory

\footnotetext{
17 Hans Kelsen, General Theory of Law and State (New Brunswick: Transaction Publishers, 2006): 351. Hans Kelsen says that a state is an international body acting as a person. Therefore, the creation and the execution of an order is a function of its organ and the international legal order is created and executed by the state. Nevertheless, the norm of international law is incomplete and it needs legalisation of the norm of national law.

18 Jochen Von Bernstorff, "Hans Kelsen and the Return of Universalism," in The Oxford Handbook of the Theory of International Law, ed. Anne Orford, Florian Hoffman and Martin Clark (United Kingdom: Oxford University Press, 2016), 210.

19 Bruno Simma, "The Contribution of Alfred Verdross to the Theory of International Law," Eur. J. International 6, L.33 (1995): 37.

20 Ibid.: 38

${ }^{21}$ Geoff Gordon, "Natural Law in International Legal Theory, Linear and Dialectical Presentations,", in The Oxford Handbook of the Theory of International Law, ed. Anne Orford, Florian Hoffman and Martin Clark, 305. United Kingdom: Oxford University Press, 2016.

22 The Preamble of the French Constitution, par. 14, 27 October 1946.

${ }_{23}$ Ibid., par. 15.

24 Roger Errera, "L'application de la Convention internationale relative aux droits de l'enfant et l'incidence de
} 
assumes that there is no distinction between the national legal order and the international legal order since ratification laws are still needed to transform and create the international legal order alongside and within the national legal order. ${ }^{25}$

Concerning the dualism theory, national law and international law are hermetically separated with no relationship between the two and each law evolves in its own sphere so that the international law cannot be applied to the national for two reasons. The first reason is that the objects and the subjects of the national and international laws are completely different. The subjects of the international law are the states and the relationships are horizontal, whereas in national law the subjects are the private persons and the relationships are vertical. The second reason that the sources are different is that the rules in national law come from the individual and the highest volition comes from the state. On the other hand, in international law there is a common willingness to create legislation. ${ }^{26}$

Christine Kaufmann and Johannes Chan express that dualistic countries need to incorporate international treaties into their national legal systems and each country decides where to place an international treaty in its national hierarchy of norms. ${ }^{27}$ According to Hans Kelsen, dualism is the theory that international law and state law do not constitute a unified system of law but exist instead independently of one another. ${ }^{28}$ As Kelsen puts it, dualism sees "international law and state law as two different systems of norms, independent of each other and reciprocally isolated because of resting on two different basic norms". 29

\footnotetext{
la Convention Européenne des droits de l'homme sur les droits de l'enfant, Comité franco - britannique de coopération judiciaire [The application of the international Convention of the Rights of the Child and the impact of the European Convention on Human Rights to the Child, Franco-British Committee on Judicial Cooperation]" (Paper at the Rennes Symposium, 19 - 21 May 2005. https://www.courdecassation.fr/IMG/File/errera_fr.pdf.

25 David Capitant and Karl-Peter Sommermann, "Actualité du Droit Public Comparé en France et en Allemagne: Actes des Séminaires Franco-Allemandes de Droit Public Comparé 2006-2007 [Actuality of the Public Law compared in France and Germany: Acts of the Seminars French-Germany of Comparative Public Law 2006-2007]", Société de legislations compare [Comparative Legislation Society] (2009): 28.

26 "L'application du droit international."

27 Kaufmann and Chan, "The relationship between" 10.

28 Hans Kelsen, Introduction to the Problems of Legal Theory (Oxford: Oxford University Press, 1992). Cited in Torben Spaak, "Kelsen on Monism and Dualism" in Basic Concepts of Public International Law: Monism \& Dualism, ed. Marko Novakovic, 322-343 (Belgrade: Alter DOO and Faculty of Law, University of Belgrade, Institute of Comparative Law), 2016.
}

29 Ibid. 
Protocol Number 13 Year 2002 of the Convention for the Protection of Human Rights and Fundamental Freedoms concerning the Abolition of the Death Penalty in all circumstances ${ }^{30}$ is a good example that describes the theories of monism and dualism regarding the signature and ratification of international treaties. In this context, Article 6 stipulates,

This protocol shall be open for signature by member States of the Council of Europe which have signed the Convention. It is subject to ratification, acceptance or approval. A member state of the Council of Europe may not ratify, accept or approve this Protocol without previously or simultaneously ratifying the Convention. Instrument of ratification, acceptance or approval shall be deposited with the Secretary General of the Council of Europe. ${ }^{31}$

In this regard, we can see that a state who embraces monism theory accepts and directly applies an international treaty. On the other hand, a state that embraces dualism theory does not apply an international treaty directly because it binds a state at the international level and cannot be applied directly by national justices ${ }^{32}$. Therefore, ratification by transforming the international treaty must be discussed in parliament in order that an international treaty can be implemented into the national legal system.

From my point of view, the Indonesian constitution does not clearly stipulate the correlation between international and national law. It is very different in France where the correlation between these two laws are stipulated firmly in Article 55 of the French constitution: "Treaties or agreements duly ratified or approved shall, upon publication, prevail over Acts of Parliament, subject, with respect to each agreement or treaty, to its application by the other party."${ }^{33}$

\footnotetext{
30 This protocol was signed by France on 3 May 2002. France ratified the Protocol Number 13 Year 2002 to the Convention for the Protection of Human Rights and Fundamental Freedoms concerning the Abolition of the Death Penalty in all circumstances on 10 October 2007 and it came into force on 1 February 2008.

${ }^{31}$ The Protocol Number 13 Year 2002 to the Convention for the Protection of Human Rights and Fundamental Freedoms concerning the Abolition of the Death Penalty in all circumstances, Art. 6, 3 May 2002.

32 Franck Moderne, La Convention Européenne des Droits de l'Homme: texte integral de la Convention de sauvegarde des droits de l'homme [The European Convention on Human Rights: full text of the Convention for the protection of human rights], Edition Dalloz (2012): 10.

33 The French Constitution, Art. 55, 4 October 1958.
} 
Furthermore, based on the Indonesian national law, particularly Law Number 24 Year 2000 regarding the International Treaties and Law Number 12 Year 2011 regarding the Formation of the Establishment of Regulation of Law, these two laws guarantee the ratification of international treaties becoming integral parts of national law. Article 10 of Law Number 24 Year 2000 regarding International Treaties and Article 10 paragraph (1) of Law Number 12 Year 2011 regarding the Formation of the Establishment of Regulation of Law stipulate that the legalisation of international treaties is performed by law. However, it does not mean that the Indonesian legal system does not have any problems concerning international treaties.

The explication of Law Number 24 Year 2000 declares,

As the most important part of the process of making the treaty, the ratification of the treaty needs to be deeply concerned considering at that stage a state is officially committed to the treaty. In practice, the form of legalization is divided into four categories, namely (a). ratification if a country which will ratify a treaty agrees to sign the treaty; (b). accession if the country which will validate an international agreement does not sign the agreement; (c). acceptance and approval are a statement of acceptance or approval of a State party in an international agreement to amend the treaty. In addition, there are also international agreements that do not require validation and they can be applied directly after signing. ${ }^{34}$

Noticing the explanation above, we can recognise a legal problem in that Indonesia imposes international treaties differently into national law. Moreover, Law Number 24 Year 2000 regarding International Treaties and Law Number 12 Year 2011 regarding the Formation of the Establishment of Regulation of Law do not explain clearly the reasons and criteria that international treaties require a legalisation process, but on the other hand, there are international treaties that may be applied directly after signing. As a result, there is no clarity concerning the position of international treaties in the national law of Indonesia.

It is possible to develop the theory of dualism by assigning superiority to international law. In this regard, the author suggests that Indonesia should

34 The explication of Law Number 24 Year 2000 regarding International Treaties, dated 23 October 2000, additional of Official Gazette number 4012. 
embrace the dualism theory of the superiority of international law for two reasons. The first reason the character of the Indonesian constitution is dualists that it does not explain the position of international treaties in its legal system. Moreover, the character of the Indonesian constitution is to protect the state's sovereignty and adat law societies/customary law along with their traditional rights as mentioned in Article 18B paragraph (2) of the Indonesian Constitution. A French jurist, Adéhar Esmein, suggests the sovereignty doctrine that

public power and government exist only in the interest of all the members who compose the nation. From which one may readily conclude that what is established in the interest of all ought to be ruled by those interested, by the general will, by all the citizens participating in its establishment, subject only to the rule of the majority. ${ }^{35}$

Thus, the international cooperation between countries and/or international organisations must prioritise the interest of people national necessities. The second reason is that national law cannot be used to justify an infringement of international law, so that every country is bound to perform the international law in good faith as mentioned in Articles 26 and 27 of the Vienna Convention on the Law of Treaties 1969. In other words, Indonesia should prioritize the international law after its ratification into the national legal system.

\subsubsection{The Ratification Approval of the Integration of International Treaties into the National Legal System}

France and Indonesia regulate the ratification of international treaties in their constitutions and laws. The presidents of these two countries have a very important role in conducting foreign policies. In this context, Article 52 of the French constitution stipulates, "The President of the Republic shall negotiate and ratify treaties. He shall be informed of any negotiations for the conclusion of an international agreement not subject to ratification". ${ }^{36}$ On the other hand, Article 11 paragraph (2) of the Indonesian constitution stipulates, "The President when concluding other international treaties that give rise to extensive and

\footnotetext{
35 Adéhar Esmein, Eléments de droit constitutionnel [Elements of Constitutional Law], 6th edition (Paris: Recueil Sirey, 1914): 280.

${ }^{36}$ Article 52 of the France Constitution, Official Journal of the Republic of France number 9151, dated 5 October1958.
} 
fundamental consequences to the life of the people related to the financial burden of the state, and/or compelling amendment or enactment of laws shall be with the approval of the People's Representative Council." ${ }^{7}$ However, Article 11 of the Indonesian constitution has not stipulated the mechanism of making international treaties and the position of international treaties in the Indonesian national legal system..$^{8}$

As the executive branch of power, the government is also responsible for diplomatic questions because matters of foreign affairs are under its authority, in particular the Ministries of Foreign Affairs in both France and Indonesia. However, the Presidents of the Republic in both countries have a real superiority, especially when customarily imposed as the head of state.

In ratifying international treaties, the French parliament ${ }^{39}$ also makes an intervention as stated in Article 53 of the French Constitution:

Peace treaties, commercial treaties, treaties or agreements concerning international organization, those who modify provisions of legislative nature, those who are relative to the state of the people, those who contain exchange or addition of territory, cannot be ratified or approve that by virtue of law. They come into effect only having been ratified or approved. No disposal, no exchange, no addition of territory is valid without the consent of the interested populations..$^{40}$

In other words, this article means that international treaties require legislative authorisation. If the parliament refuses the authorisation, the president cannot ratify international treaties. The Committee on Foreign Affairs plays an important role in this procedure. It is, in particular, responsible for the examination of all agreements submitted to Parliament. However, parliamentary assemblies cannot

37 Article 11 paragraph (2) of the Third Amendment of the Indonesian Constitution, dated 1-9 November 2001. Moreover, Article 11 paragraph (3) of the Indonesian constitution stipulates that further provisions regarding international treaties shall be regulated by laws. The law is needed because the Indonesian Constitution only regulates basic norms of international treaties.

${ }^{8}$ Dhiana Puspitawati and Adi Kusumaningrum, "Reposisi Politik Hukum Perjanjian Internasional Dalam Rangka Mewujudkan Tertib Hukum di Indonesia [Law Political Reposition of International Treaty in order to implement legal order in Indonesia]," Jurnal Media Hukum 22, no. 22 (2015): 270.

39 Based on Article 24 of the French constitution, the French parliament is the bicameral legislature of the Republic of France which consists of the National Assembly and the Senate. The National Assembly consists of 577 directly elected members, and the Senate consists of 348 indirectly elected members who represent the territorial collectivities.

40 Article 53 of the French Constitution, Official Journal of the Republic of France number 9151, dated 5 October1958 
amend the text of international conventions. ${ }^{41} \mathrm{After}$ Parliament has authorised or approved the ratification of international treaties, it does not necessarily intervene immediately when all states of the European Union decide to ratify an agreement on the same day. ${ }^{42}$ The French constitution also stipulates in Article 55, "Treaties or agreements duly ratified or approved shall, upon publication, prevail over Acts of Parliament, subject, with respect to each agreement or treaty, to its application by the other party." ${ }^{33}$ In Indonesia, the parliament also intervenes in the ratification of international treaties. It is determined in Article 11 of paragraph (1) of the Indonesian constitution that "The President with the approval of the People's Representative Council declares war, makes peace and concludes treaties with other countries".44

The national law can ratify an international treaty that a state has approved in the manner of commitment to international treaties. It is the same manner as stipulated in Article 3 of Law Number 24 Year 2000 regarding International Treaties that the Indonesian government binds itself to international treaties through signing, ratification, the exchange of treaty documents/diplomatic notes and other ways as agreed by the parties concerned. ${ }^{45}$ However, there are differences between a signature and ratification regarding international treaties. A signature does not legally bind the signatories of international treaties because it only shows their willingness to complete the negotiation process to the end..$^{46}$ If there is a commitment, it is only a moral willingness. In order that international treaties have legally binding power and come into force, they must be ratified by the competent authority, namely the President and the House of Representatives. After the process of ratification is completed, international treaties are published in the official journal or official gazette in order to bind citizens nationally.

\footnotetext{
${ }_{41}$ Assemblée Nationale [National Assembly], "Fiche de synthèse $n^{\circ} 42$ : La ratification des traités [Summary sheet number 42: Ratification of Treaties]."

$4^{2}$ Ibid.

43 The French constitution, Art. 55, Official Journal of the Republic of France,number 9151, 4 October 1958.

44 The Indonesian Constitution, Art. 11, par. 1, amend. 4, 1-11 Augusts 2002.

45 International Treaties, Art. 3, Law Number 24, 2000.

${ }_{46}$ It is in line with the explanation of Article 6 paragraph (2) of Law Number 24 Year 2000 regarding International Treaties, which stipulated that the signing of an international treaty cannot be interpreted as a commitment to the agreement. The signing of an international treaty that requires ratification does not bind the parties before the treaty is ratified.
} 
There is an interesting question: why is the signature itself not legally binding to a country? The answer is when a state signs international treaty, it is only the executive who signs. It does not reflect the will of the whole country. Therefore, the opinion of the House of Representative is needed to consider whether a state needs to ratify international treaties for the national purpose. However, the constitutional law in France does not recognise "acceptance" but only "approval"; the executive will adopt a national measure of approval and will announce it as being worth "acceptance" in the meaning of treaty. ${ }^{47}$

The influence of international treaties can also be indirect or diffuse. It means that international treaties are signed, but perhaps they are not ratified by a state and they have not come into effect nationally; however, occasionally it is admitted that the text of international treaties can be applied immediately, although it is not an obligation..$^{8}$

\subsection{The Rank of International Treaties in the National Legal System}

It is important to discuss the rank of international treaties in the national legal system. The author refers to the Venice Commission's report on the implementation of international human rights treaties in domestic law and the role of courts, which expresses that the status of treaties in the domestic legal order and their place in the hierarchy of norms has an impact on the implementation of human rights treaties. ${ }^{49}$

\subsubsection{The Superiority of International Treaties over the National Laws in France}

The principle of superiority means that international law (i.e. all positive international law and not only treaties) prevails over the whole body of domestic law, constitutional norms, legislative, regulatory, judicial decisions and international judges..$^{50}$ France has stated this in its constitution, with international recognition as

47 Raphaële Rivier, Droit international public [Public International Law], Presses Universitaires de France/Humensis (2017): 60.

$4^{8}$ Michel Prieur, "L'influence des conventions internationales sur le droit interne de l'environnement" [The influence of international convention on the environment of internal law], Acts of the essential meeting of the committee on the environment of the AHJUCAF (June 2008): 294.

49 Bilkova, "Report on the," 6.

50 Dominique Carreau and Fabrizio Marrella, Droit International [International Law] (Paris : Pedone, 2012 ): 80. 
part of their internal system. In this regard, ratified international treaties are the source of international law. Once international treaties are ratified by Parliament, international treaties have a binding legal force superior to the national law. ${ }^{51}$

Noticing the norms pyramid below, we can see the position of international treaties in the French legal system: ${ }^{2}$

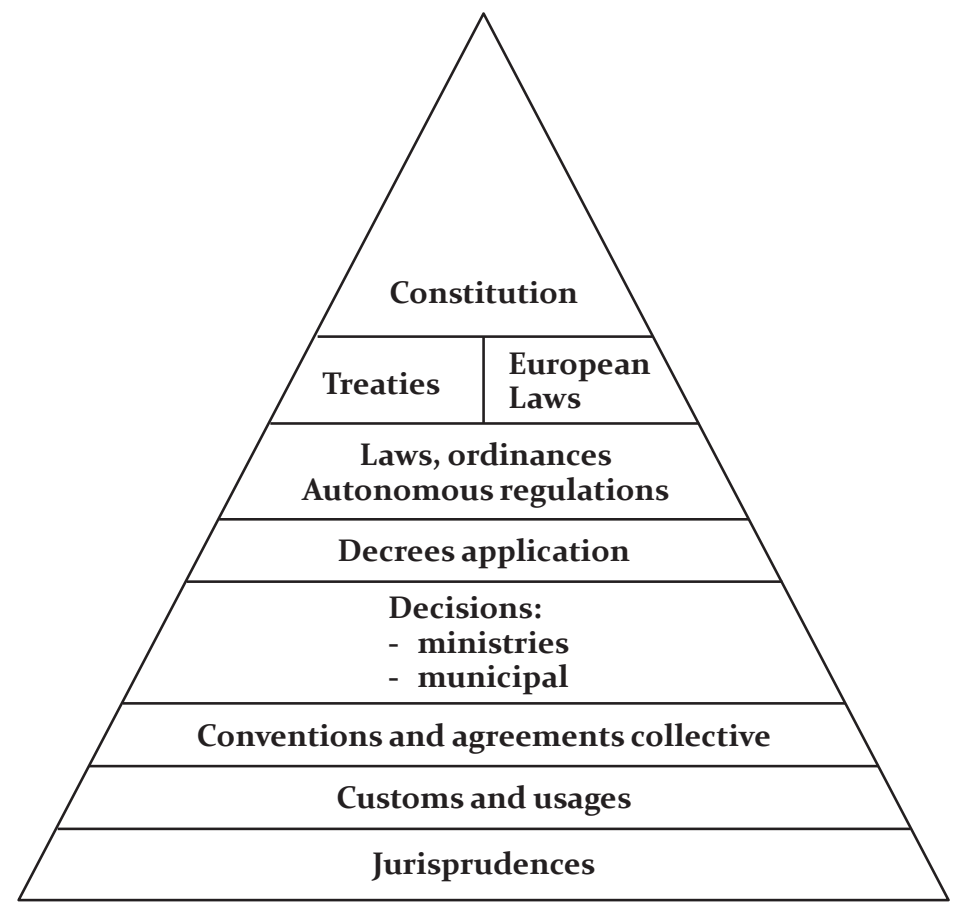

Based on the hierarchy of norms above, we notice that the Constitution is the fundamental norm of the French legal system. Moreover, we see that international treaties are below the Constitution, but above national laws. However, the French constitution does not mention this hierarchy of norms and Article 55 of the French constitution only indicates that international treaties have a value superior to national laws.

\footnotetext{
${ }^{1}$ Université Paris 1 Panthéon Sorbonne, "Introduction Générale au système juridique français et à la méthodologie [General Introduction to the French Legal System and Methodology]" (2016), 3.

52 lbid., 9.
} 
In the context of the control of conventionality, the European Convention on Human Rights is considered as a standard international humanitarian treaty.53 In this regard, the judges' role is at the international level exclusively. They will not interpret the contested national legal rulings in matters of international law norms. If they find a contradiction between a national legal ruling and the international legal ruling, they will declare that the national legal rule is "ineffective", or quite simply "not applicable", at the international level.54

Under Article 46 of the European Convention on Human Rights, a state is bound to abide by a judgment to which it is a party and so their supreme and constitutional courts are bound by the Court's interpretation of the Convention and findings as to a violation of the Convention. If the court or the supreme or the constitutional courts of a state are of the opinion that the origin of a violation is a result of the state's constitution, the national courts should first seek to interpret the national constitution in accordance with the Convention. If this is not possible, the state should amend its constitution to bring it in line with the Convention (as interpreted by the Court). This is the case even where a state's national constitution has a higher rank in the state's hierarchy of laws than the Convention. 55

\subsubsection{The Equal Position and the Inferiority of International Treaties to National Laws in Indonesia}

In Indonesia, the ratification of certain international treaties must be regulated by national laws. ${ }^{56}$ Therefore, certain international treaties have the same position as national laws. The definition of certain international treaties is mentioned in the explication of Article 10 paragraph (1) letter c:

Certain international treaties are international treaties which cause widespread and fundamental consequences for the lives of people related to the state's financial burden and/or those treaties require changes or the establishment of law with the approval of the House of Representatives. ${ }^{57}$

53 France ratified the European Convention on Human Rights on 3 May 1974.

54 Carreau and Marrella, Droit International [International Law], 85.

55 Council of Bars and Law Societies of Europe, "The European Court of Human Rights, Questions and Answers, Brussels (2016)" 21.

56 Law Number 12 Year 2011 regarding the Establishment of the Laws and Regulation, Art. 10, par. 1, letter c.

57 The explication of Law Number 12 Year 2011 regarding the Establishment of the Laws and Regulation. 
Article 10 of Law Number 24 Year 2000 regarding International Treaties stipulates,

The ratification of international treaties is made by the national law for the following matters: a. issues of national politics, peace, defense and national security; $b$. the change of territory or the determination of the Indonesian territory; c. sovereignty or sovereign rights of the state; d. human rights and environment; e. the establishment of new legal rules; f. foreign loans and/or grants.

On the other hand, Article 11 paragraph (1) of Law Number 24 Year 2000 regarding International Treaties stipulates, "The ratification of an international treaty whose matter is not included in Article 10 is made by a presidential decree". Based on these two articles, the rank of international treaties is the same as national laws and also below national laws. Therefore, international treaties occupy two positions in the national legal system in Indonesia depending on their content. We can see the rank of international treaties in the norms pyramid below: ${ }^{8}$

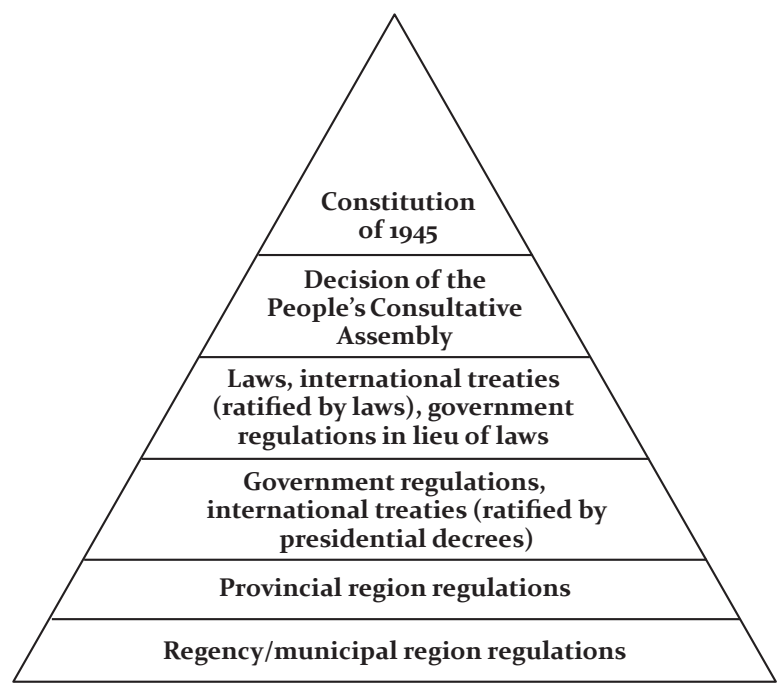

Concerning the hierarchy of norms, in Decision number 13/PUU-XVI/2018, the Indonesian Constitutional Court was of the opinion that the Indonesian constitution does not require certain legal forms to express the approval of the

$5^{8}$ Law Number 12 Year 2011 regarding the Establishment of the Laws and Regulation, Art. 7, par. 1. 
House of Representatives for international agreements ratified by a Presidential Decree. It gives freedom to the President to implement government functions, particularly in relation to international relations, and the President considers both Indonesia's national interests and the norms accepted universally by the international community. ${ }^{59}$

\subsection{The Practices in Examining Cases of International Treaties in France and Indonesia}

Before discussing international treaty cases in France, the author discusses the similarity and the difference of constitutional case examinations in France and Indonesia.

France and Indonesia share similarities in the context of reviewing the conformity of law with their constitutions after promulgation. In Indonesia, the Constitutional Court review laws against the Constitution. ${ }^{60}$ In France, the Constitutional Council controls the conformity of law with the Constitution after the promulgation of law. ${ }^{61}$ It is called contrôle concret (concrete control) in French. Officially, this control is called "QPC" (question prioritaire de constitutionnalité/ Priority Question of Constitutionality) and came into effect on 1 March 2010. ${ }^{62}$

France and Indonesia have three differences in examining constitutional cases. The first difference is access to the Court. The Indonesian Constitutional Court implements direct access to the Court. ${ }^{63}$ However, the Constitutional Council (le Conseil Constitutionnel) of France implement indirect access to the Court because the Cassation Court (la Cour de Casssation) and the State Council (le Conseil d'Etat) filter the case before the Constitutional Council examine it. ${ }^{64}$ The second difference is judicial preview of law. In France, judicial preview of law is called contrôle a priori or contrôle abstrait, which means reviewing the

59 The Decision of the Constitutional Court of Indonesia Number 13/PUU-XVI/2018, dated 19 November 2018: 261.

60 The Indonesia Constitution 1945, Art. 24C and Law Number 24 Year 2003 regarding the Constitutional Court Art. 10, par. 1 letter a.

61 The French Constitution Art. 61-1 and Law Number 2008-724 on 23 July 2008 regarding the modernisation of the institutions of the Fifth Republic of France, Art. 29.

62 https://www.conseil-constitutionnel.fr/nouveaux-cahiers-du-conseil-constitutionnel/entree-en-vigueur-de-l-article61-1-de-la-constitution-discours-de-jean-louis-debre.

63 It is in line with Article 29 of Law Number 24 Year 2003 on the Constitutional Court, which stated, "A petition shall be filed in writing in Indonesian by the petitioner or his/her proxy to the Constitutional Court".

64 The French Constitution, Art. 61-1 and Law Number 2008-724 on 23 July 2008, Art. 29. 
conformity of law with the constitution before its promulgation. ${ }^{65}$ In contrast, Indonesia does not have a system of judicial preview of law. Contrôle abstrait and contrôle concret are controls of norms with an aim to control the conformity of norms applied to the constitution and the fundamental rights. ${ }^{66}$ The third difference is the control of conventionality. In this regard, France implements le contrôle de conventionnalité (control of conventionality) conducted by European Court of Human Rights. On the other hand, Indonesia does not implement any control of conventionality.

The European Court of Human Rights has the authority to control the human rights conventions not only in France but also 47 states around Europe. To submit an application to the European Court of Human Rights, an applicant must exhausted all the remedies in the state concerned that could provide redress for their situation (usually, this will mean an application to the appropriate court, followed by an appeal, where applicable, and even a further appeal to a higher court such as a supreme court or constitutional court, if there is one) ${ }^{67}$

In reaching its decision, the European Court of Human Rights considers if there is an infringement of the European Convention on Human Rights. Three cases (Mugenzi v. France ${ }^{68}$, Tanda-Muzinga v. France ${ }^{69}$ and Senigo Longue and Others v. France ${ }^{70}$ ) concerned the difficulties in obtaining visas for the applicants' children. The applicants alleged that the refusal by the consular authorities to issue visas to their children for the purpose of family reunification had infringed their right to respect for their family life. The European Court of Human Rights observed in particular that the procedure for examining applications for family reunification had to contain a number of elements, having regard to the

\footnotetext{
65 Articles 54 and 61 of the French constitution; Articles 17 and 18 of the Ordonnance Number 58-1067.

66 David Capitant, Les Effets Juridiques des Droits Fondamentaux en Allemagne [Legal Effects of Fundamental Rights in Germany], Libraire Générale de Droit et de Jurisprudence [General Library of Law and Jurisprudence, E.J.A and David Capitant], E.J.A et David Capitant (2001), 98.

${ }_{67}$ European Court of Human Rights, "Questions and Answers", Council of Europe, Strasbourg: 6. Article 35 paragraph (1) of the European Convention on Human Rights stipulates, "The European Court of Human Rights may only deal with the matter after all domestic remedies have been exhausted, according to the generally recognized rules of international law, and within a period of a six months from the date on which the final decision was taken. After that period, the application cannot be accepted by the Court".

68 The Decision of European Court of Human Rights No. 52701/og.

69 The Decision of European Court of Human Rights No. 2260/10.

70 The Decision of European Court of Human Rights No. 19113/og.
} 
applicants' refugee status on the one hand and the best interests of the children on the other, so that their interests as guaranteed by Article 8 (right to respect for private and family life) of the European Convention on Human Rights from the point of view of procedural requirements were safeguarded. In all three cases, the Court held that there had been a violation of Article 8 of the Convention. Since the national authorities had not given due consideration to the applicants' specific circumstances, it concluded that the family reunification procedure had not offered the requisite guarantees of flexibility, promptness and effectiveness to ensure compliance with their right to respect for their family life. For that reason, the French state had not struck a fair balance between the applicants' interests on the one hand, and its own interest in controlling immigration on the other..$^{71}$

The implementation of international treaties in domestic law is often achieved by an interpretation of domestic courts in their decisions. The confrontation between national and international law can be avoided by harmonising the domestic courts' decisions as we can see in the decisions below.

In France, a preliminary review of the compatibility of international treaties is required to examine whether international treaties can be ratified and their norms are not contradictory to the Constitution. According to the Venice Commission, courts are needed to resolve the conflict between international treaties and national law. The Venice Commission explains, "two main options are available: the first one consists in the harmonisation of the conflicting provisions through interpretation; the second one is based on the hierarchy of norms, which implies either the disapplication of domestic law or ignoring the international human rights treaty".72

The Constitutional Council of France uses the European Convention on Human Rights in a judicial review procedure of non-ratified treaties. ${ }^{73}$ Based

71 "The Children's Right," The European Courts of Human Rights, https://www.echr.coe.int/Documents/FS_Childrens_ ENG.pdf.

72 Bilkova, "Report on the...," 35.

73 Faculté de Droit est Sciences sociales Université de Poitiers [Faculty of Law and Social Science of Poitiers University], Les Normes de Référence du Contrôle de Constitutionnalité [Reference Norms of Judicial Review] (LGDJ, 2017), 40. 
on Article 54 of the French constitution, ${ }^{74}$ the Constitutional Council made a reference to the European Convention of Human Rights and the judgement of the European Court of Human Rights in Decision Number 2004-505, dated 19 November 2004. It is a decision concerning the compatibility of the European and French constitutions. In Point 13 of its decision, the Constitutional Council of France concluded that, based on the primacy principle of the European Union, there would be no need to amend the French constitution. ${ }^{75}$ Moreover, in Point 17 of its decision, the Constitutional Council mentioned that the explanations drawn up as a way of providing guidance for the interpretation of the Charter of Fundamental Rights shall be given due regard by courts of the Union and of member states. ${ }^{76}$ Then, it was noted that Article 9 of the European Convention on Human Rights guarantees the protection of the rights and freedoms of others. ${ }^{77}$

Another important case examined by the Constitutional Council of France is Decision Number 74-54 DC ofi5 January 1975. In its decision, the Constitutional Council of France decided, pursuant to Article 61 of the French Constitution, ${ }^{78}$ it did not have any authority to examine the conformity of law to international treaties because its authority was in examining the conformity of law to the constitution. Furthermore, the Constitutional Council of France decided that the control of international treaty superiority (the control of conventionality) should be done by the ordinary courts under the supervision of the Cassation Court and the State Council. ${ }^{79}$

\footnotetext{
74 Article 54 of the French Constitution stipulates, "If the Constitutional Council, on a referral from the President of the Republic, from the Prime Minister, from the President of one or the other Houses, or from sixty Members of the National Assembly or sixty Senators, has held that an international undertaking contains a clause contrary to the Constitution, authorization to ratify or approve the international undertaking involved may be given only after amending the Constitution."

75 The Decision of the Constitutional Council of France number 2004-505 DC, point 13: 4, dated 19 November 2004.

76 Ibid., point 17: 5 .

77 Ibid., point 18: 5 .

78 Article 61 of the French Constitution stipulates, "Institutional Acts, before their promulgation, Private Members' Bills mentioned in article 11 before they are submitted to referendum, and the rules of procedure of the Houses of Parliament shall, before coming into force, be referred to the Constitutional Council, which shall rule on their conformity with the Constitution. To the same end, Acts of Parliament may be referred to the Constitutional Council, before their promulgation, by the President of the Republic, the Prime Minister, the President of the National Assembly, the President of the Senate, sixty Members of the National Assembly or sixty Senators. In the cases provided for in the two foregoing paragraphs, the Constitutional Council must deliver its ruling within one month. However, at the request of the Government, in cases of urgency, this period shall be reduced to eight days. In these same cases, referral to the Constitutional Council shall suspend the time allotted for promulgation."

79 The Decision of the Constitutional Council of France number 74-54 DC on 15 January 1975.
} 
The Cassation Court of France responded to the decision of the Constitutional Council on 24 May 1975 in the case of Société des Cafés Jacques Vabre (Jacques Vabre Coffee Company) while the State Council of France took longer to respond to the decision of the Constitutional Council on 20 October 1989 in the case of Nicolo. ${ }^{80}$ The legal consideration of French judges to exclude the application of law contrary to international treaties is the same as the legal arguments of Chief Justice Marshall in the case of Marbury v. Madison in 1803 in the Supreme Court of the United States of America. ${ }^{81}$

In Indonesia, the Supreme Court and the Constitutional Court are experienced in examining cases regarding international treaties. In the judgement of the Supreme Court Number 2944K/PDT/1983 on the case of PT Nizwar vs Navigation Maritime Bulgare, the Supreme Court did not accept the application of PT. Nizwar because the applicant did not apply the minutes of cassation which contains the legal reasons as stipulated in Article 115 paragraph (1) of Law regarding the Indonesian Supreme Court. Moreover, the Supreme Court was of the opinion that the decision of the foreign court and the decision of a foreign arbitration judge cannot be implemented in Indonesia unless there is an agreement between the Republic of Indonesia and a foreign country to implement the decision of the foreign court/the decision of the arbitration judge. The Supreme Court was also of the opinion that Presidential Decree Number 34 of 1981, dated 15 August 1981, regarding the Ratification of the Convention of the Recognition and Enforcement of Foreign Arbitral Awards must be regulated further as to whether the execution request of a judge's arbitration decision can be submitted directly to the District Court or the request for execution is applied to the Supreme Court in order to consider whether the judge's arbitration decision does not contain matters which are contradictory to the law in Indonesia. ${ }^{82}$

In 2011, the Indonesian Constitutional Court examined a judicial review case concerning the Ratification of the Charter of the Association of Southeast Asian Nations. In the decision number 33/PUU-IX/2011, the Constitutional Court

80 Olivier Dutheillet de Lamothe, "Contrôle de conventionnalité et contrôle de conventionnalité en France [The Control of Conventionality and the Judicial Review in France]."

81 Ibid.

82 The Decision of the Supreme Court of Indonesia Number 2944K/PDT/1983, dated 29 November 1984. 
referred to Article 2 paragraph (1) letter b of the Vienna Convention of the Law of Treaties which stipulates, "ratification", "acceptance", "approval" and "accession" mean in each case the international act so named whereby a state establishes on the international plane its consent to be bound by a treaty. ${ }^{83}$

In 2018, the Indonesian Constitutional Court examined a judicial review of Law Number 24 Year 2000 regarding the International Treaty. In this case with the decision number 13/PUU-XVI/2018, the Constitutional Court also referred to the Vienna Convention as follows:

Whereas in the field of international law, regulations regarding international agreements between countries apply the provisions stipulated in the Vienna Convention 1969 concerning the Law of International Treaties, it is emphasized in Article 1 of the Vienna Convention 1969, which stated, "The present Convention applies to treaties between States." In addition, based on Article 2 paragraph (1), the Vienna Convention 1969 also does not apply to unwritten international agreements between countries. Whereas international treaties between countries and international organizations or among international organizations are stipulated in the Vienna Convention 1986 (Vienna Convention on the Law of Treating Between and International Organizations). It is affirmed in Article 1 of the Vienna Convention 1986 which states, "The present Convention applies to: (a) treaties between one or more States and one international organization, and (b) treaties between international organizations." Article 3 of the Vienna Convention 1986, states that this Convention does not apply: (i) to international agreements in which one or more countries, one or more international organizations and one or more subjects of international law other than the state or international organization are parties; (ii) to international agreements where one or more international organizations and one or more subjects of international law other than the state or international organization are parties; (iii) towards international agreements that are in an unwritten form between one or more countries and between one or more international organizations, or between international organizations. Thus, the Vienna Convention 1969 and the Vienna Convention 1986 acknowledged implicitly the existence of an unwritten international agreement between countries and international organizations. However, it is beyond the scope of the regulation of the two conventions. In other words, implicitly, the regulation of international agreements in an unwritten form is ceded to practice that applies outside the provisions of the two conventions mentioned. ${ }^{\prime 84}$

$8_{3}$ The Decision of the Constitutional Court of Indonesia Number 33/PUU-IX/2011, dated 26 February 2013: 195.

84 The Decision of the Constitutional Court of Indonesia Number 13/PUU-XVI/2018, dated 19 November 2018: $252-253$. 
The intention of the House of Representative's approval in Article 11 paragraph (1) and paragraph (2) of the Constitution 1945 is an international treaty whose process of formation is through 3 stages. In this regard, the Court affirms that according to the Vienna Convention 1969, statements to be bound in an international treaty can be made through signature, exchange of instruments constituting a treaty, acceptance, approval, accession or statement of participation, or any other means if so agreed. It is also affirmed in Article 6 paragraph (2) of Law 24 Year 2000, in conjunction with Article 15 paragraph (1). Article 6 paragraph (2) of Law 24 Year 2000 states, "The signing of an international treaty is an agreement on the text of the international agreement that has been resulted and/or is a statement to bind itself definitively in accordance with the parties' agreement". ${ }^{5}$

Noting the decisions of the Indonesian Supreme Court and the Indonesian Constitutional Court above, we can see the ambivalence of international treaties implementation by Indonesian courts. In this regard, the Supreme Court refused the implementation of the Convention on the Recognition and Enforcement of Foreign Arbitral Awards, although this convention had been ratified by Presidential Decree Number 34 of 1981 on 5 August 1981. On the other hand, the Constitutional Court referred to the Vienna Convention of the Law of Treaties although Indonesia did not ratify this treaty. The constitutional justices used the Vienna Convention of the Law of Treaties to strengthen their legal opinion in the decision and they decided based on their beliefs, independently.

The interesting question is how to resolve the problem of international treaty implementation in Indonesia. In the opinion of the author, national law cannot obstruct the implementation of international law. Therefore, we should clarify the relationship between international and national law. The author has suggested this in order that Indonesia might embrace the dualism theory of the superiority of international law.

In the context of judicial power, we cannot impede a court from examining an international treaty. Therefore, we should create a legal invention in order that a court can examine an international treaty. In his article, Noor Sidharta was of the opinion that, "the Indonesian Constitutional Court can do judicial preview of the ratification of international treaties by adding the rights of the Constitutional

${ }_{85}$ The Decision of the Constitutional Court of Indonesia Number 13/PUU-XVI/2018, dated 19 November 2018: 258. 
Court into the Constitution of 1945 and through the state of administration, namely at the request of the People's Representatives Council". ${ }^{86}$ The author would like to complete his opinion that judicial preview by the Constitutional Court can be applied by the President of the Republic of Indonesia, the President of the House of Representatives or at least one tenth of the members of the House of Representatives. It means that the minority of members of the House of Representatives can apply for judicial preview the Constitutional Court.

The question is why a case of judicial preview should be applied by one tenth of the members of the House of Representatives. Compared to France, an international agreement can be applied to the Constitutional Council before its ratification by the President of the Republic, by the Prime Minister, by the President of one or the other Houses, or either by 6o (sixty) members of the National Assembly or 6o (sixty) senators. ${ }^{87}$ The National Assembly consists of 577 members and the Senate consists of 348.If we count, 6o (6o refers to the 60 members of the National Assembly who apply for a judicial preview case to the Constitutional Council) divided by 577 (577 refers to the amount of members of the National Assembly) equals to one tenth. Based on this calculation, the author concludes a case of judicial preview on international treaty can be applied to the Indonesian Constitutional Court at least by one tenth of the members of the House of Representatives. The judicial preview is a legal effort as a preventative measure in order to protect Indonesia's national interests from unjust international treaties.

Another legal problem which must be resolved is whether a court in Indonesia might examine an international treaty after it has been ratified and which court might examine it. Therefore, the author suggests that the Indonesian Constitutional Court can examine the ratified international treaty because the nature of the control of conventionality is the same as a judicial review of the law. Moreover, the form of the international treaty is law after being ratified. In line with the author's opinion that Indonesia should embrace the dualism

\footnotetext{
86 Noor Sidharta, "Laws of Ratification of an International Treaty in Indonesian Laws Hierarchy," Constitutional Review 3, no. 2 (2017): 186.

87 Article 54 of the French Constitution, Article 18 of the Ordonnance Number 58-1067 on the Constitutional Council, dated 7 November 1958.
} 
theory of the superiority of international law, the Constitutional Court should make an interpretation of an international treaty based on the constitution and assume that an international treaty is valid.

\section{CONCLUSION}

Every state has its own legal system in accordance to its legal culture. Therefore, it is necessary to make a comparison legal study in order to solve legal problems and complete the national legal system inspired by the foreign legal system. In the context of international treaty implementation, the comparison of legal systems in France and Indonesia is useful for improving the judicial system in Indonesia. However, the absorption of the French legal system should be modified in accordance to the Indonesian legal culture.

France embraces the monism theory and the position of international treaties are above the national law. Otherwise, Indonesia adopts the dualism theory because international treaties must be ratified and transformed into national laws. The Indonesian sovereignty is the most important element and adat law societies/customary law along with their traditional rights must be protected. However, the national law must not inhibit the implementation of ratified international treaties. Therefore, the dualism of the superiority of international law in the logical theory should be implemented in Indonesia. In this regard, Indonesia should prioritize the international law after its ratification into the national legal system.

A legal invention should be constructed in order that Indonesia can resolve the problem of international treaty implementation. In this regard, the Indonesian Constitution should be amended by adding a new authority for the Indonesian Constitutional Court to conduct judicial preview of international treaties bills. This legal effort is a preventative measure in order to preserve Indonesia's importance nationally from unfair international treaties. In addition, Indonesian Constitutional Court examines ratified international treaties with the reason that the legal nature of the control conventionality is the same as a judicial review of law. In this context, the Indonesian Constitutional Court interprets international treaties referred to the constitution. 


\section{BIBLIOGRAPHY}

Assemblée Nationale [National Assembly]. "Fiche de synthèse n ${ }^{\circ 2}$ : La ratification des traités." [Summary sheet number 42: Ratification of Treaties], http:// www2.assemblee-nationale.fr/decouvrir-l-assemblee/role-et-pouvoirs-de-lassemblee-nationale/les-fonctions-de-l-assemblee-nationale/les-fonctionslegislatives/la-ratification-des-traites_(accessed 31 July 2018).

Belou, Barrué. "Méthode et enjeux de la démarche comparative: la question de la comparabilité." [Methodology and challenges of the comparative approach : the question of comparability]. http://www.droitconstitutionnel. org/congresNancy/comN4/barrueBelouTD4.pdf (accessed 4 August 2018).

Bilkova, Veronika. et.al. "Report on the Implementation of International Human Rights Treaties in Domestic Law and the Role of Courts." Report, European Commission for Democracy through Law (Venice Commission), 2014. https://www.venice.coe.int/webforms/documents/default.aspx?pdffile=CDLAD(2014)o36-e (accessed 7 December 2018).

Capitant, David. Les Effets Juridiques des Droits Fondamentaux en Allemagne [Legal Effects of Fundamental Rights in Germany]. Libraire Générale de Droit et de Jurisprudence [General Library of Law and Jurisprudence, E.J.A and David Capitant], E.J.A et David Capitant (2001).

Capitant, David and Karl Peter Sommermann. Actualité du Droit Public Comparé en France et en Allemagne: Actes des Séminaires Franco-Allemandes de Droit Public Comparé 2006-2007 [Actuality of the Public Law compared in France and Germany : Acts of the Seminars French-Germany of Comparative Public Law 2006-2007]. Paris: Société de legislations compare [Comparative legislation society], 2009.

Carreau, Dominique and Fabrizio Marrella. Droit Interntional [International Law]. Paris: Pedone, 2012.

Constitutional Council Decision, No. 74-54 DC (The Constitutional Council of the Republic of France). 
Constitutional Council Decision, No. 2004-505 DC (The Constitutional Council of the Republic of France).

Constitutional Court Decision, No. 33/PUU-IX/2011 (The Constitutional Court of the Republic of Indonesia 2013).

Constitutional Court Decision, No. 13/PUU-XVI/2018 (The Constitutional Court of the Republic of Indonesia 2018).

Council of Bars and Law Societies of Europe, "The European Court of Human Rights, Questions and Answers, Brussels (2016).

Dumali Agusman, Damos. "Status Hukum Perjanjian Internasional Dalam Hukum Nasional Republik Indonesia, Tinjauan Dari Perspektif Indonesia [The Legal Status of International Treaties in the National Law of the Republic of Indonesia, A Review of Indonesia's Perspective]." The Indonesia Journal of International Law, vol. 5 (2008).

Dutheillet de Lamothe, Olivier. "Contrôle de conventionnalité et contrôle de conventionnalité en France [The Control Convention and the Judicial Review in France]." http://www.conseil-constitutionnel.fr/conseil-constitutionnel/ francais/publications/contributions-et-discours/2009/controle-deconventionnalite-et-controle-de-constitutionnalite-en-france.147129.html (accessed 2 October 2018).

Errera, Roger. "L'application de la Convention internationale relative aux droits de l'enfant et l'incidence de la Convention Européenne des droits de l'homme sur les droits de l'enfant, Comité franco - britannique de coopération judiciaire [The application of the international Convention of the Rights of the Child and the impact of the European Convention on Human Rights to the Child, Franco - British Committee on Judicial Cooperation]." Paper at Rennes Symposium, 19-21 May 2005. https://www.courdecassation.fr/IMG/ File/errera_fr.pdf_(accessed 25 May 2018).

Esmein, Adéhar. Eléments de droit constitutionnel [Elements of Constitutional Law], 6th edition. Paris : Recueil Sirey, 1914.

European Courts of Human Rights. "The Children's Right." https://www.echr.coe. int/Documents/FS_Childrens_ENG.pdf (accessed 10 August 2018). 
European Courts of Human Rights. "Questions and Answers." Council of Europe, Strasbourg.

European Court of Human Rights Decision, No. 52701/o9.

European Court of Human Rights Decision, No. 2260/10.

European Court of Human Rights Decision, No. 19113/o9.

Faculté de Droit est Sciences sociales Université de Poitiers [Faculty of Law and Social science of Poitiers University]. Les Normes de Référence du Contrôle de Constitutionnalité [Reference normes of judicial review], LGDJ, 2017.

Gordon, Geoff. "Natural Law in International Legal Theory, Linear and Dialectical Presentations." In The Oxford Handbook of the Theory of International Law, edited by Anne Orford, Florian Hoffman and Martin Clark. United Kingdom, Oxford University Press, 2016.

Kaufmann, Christine and Johannes Chan. "The relationship between international and national law in China, Hong Kong, and Switzerland." Paper at Seminar Comparative Constitutional Law, 2008. http://www.ivr.uzh.ch/dam/jcr:fffffffec76-c8f9-oooo-oooo4e58ddad/Pleisch_Rafaela.pdf. (accessed 5 December 2018).

Kelsen, Hans. Introduction to the Problems of Legal Theory. Oxford: Oxford University Press, 1992. Cited in Spaak, Torben. "Kelsen on Monism and Dualism." In Basic Concepts of Public International Law: Monism E Dualism, edited by Marko Novakovic, 322-343. Belgrade: Alter DOO and Faculty of Law, University of Belgrade, Institute of Comparative Law, 2016.

Kelsen, Hans. General Theory of Law and State. New Brunswick: Transaction Publishers, 2006.

Le cours de droit.net. "Lapplication du droit international dans l'ordre interne [The application of international law in the internal order]". http://www.coursde-droit.net/integration-du-droit-international-en-droit-interne-dualismemonisme-a121610042 (accessed 26 May 2018).

Moderne, Franck. La Convention Européenne des Droits de l'Homme : texte integral de la Convention de sauvegarde des droits de l'homme [The European 
Convention on Human Rights : full text of the Convention for the protection of human rights], edition Dalloz (2012).

Prieur, Michel.prieur. "L'influence des conventions internationales sur le droit interne de l'environnement [The influence of international convention on the environment of internal law]." Acts of the essential meeting of the committe on the environment of the AHJUCAF. https://hal.archives-ouvertes.fr/haloo499293 (accessed 20 June 2018).

Puspitawati, Dhiana and Ada Kusumaningrum. "Reposisi Politik Hukum Perjanjian Internasional Dalam Rangka Mewujudkan Tertib Hukum di Indonesia [Law Political Reposition of International Treaty in order to implement legal order in Indonesia]," Jurnal Media Hukum 22, no. 22 (2015).

Rivier, Raphaële. Droit international public [Public International Law]. France: Presses Universitaires de France/Humensis, 2017.

Sidharta, Noor. "Laws of Ratification of an International Treaty in Indonesian Laws Hierarchy." Constitutionnal Review 3, no. 2 (2017).

Simma, Bruno. "The Contribution of Alfred Verdross to the Theory of International Law.” Eur. J. International 6, L.33 (1995).

Sloss, David and Michael Van Alstine. "International Law in Domestic Courts." Paper at Santa Clara Law Digital Commons, 2015. https://digitalcommons. law.scu.edu/cgi/viewcontent.cgi?article=1891\&context=facpubs (accessed 30 November 2018).

Supreme Court Decision, No. 2944K/PDT/1983 (The Supreme Court of the Republic of Indonesia).

Université Paris 1 Panthéon Sorbonne. "Introduction Générale au Système juridique français et à la méthodologie [General Introduction to the French Legal System and Methodology].” 2016.

Von Bernstorff, Jochen. "Hans Kelsen and the Return of Universalism." In The Oxford Handbook of the Theory of International Law, edited by Anne Orford, Florian Hoffman and Martin Clark. United Kingdom, Oxford University Press: 2016. 